\title{
Association of plasma IgM with body size, histopathologic changes, and plasma chemistries in adult Pacific herring Clupea pallasi
}

\author{
Corrine R. Davis ${ }^{1}$, Gary D. Marty ${ }^{1, *}$, Mark A. Adkison ${ }^{2}$, Ellen F. Freiberg ${ }^{1}$, \\ Ronald P. Hedrick ${ }^{2}$
}

${ }^{1}$ Department of Anatomy, Physiology, and Cell Biology, and ${ }^{2}$ Department of Medicine and Epidemiology, School of Veterinary Medicine, University of California, One Shields Avenue, Davis, California 95616, USA

\begin{abstract}
Pacific herring Cluped pallasi immunoglobulin is an IgM-like molecule comprised of heavy and light chains with molecular weights of 79 and 25 to $27 \mathrm{kD}$, respectively. Purified immunoglobulin was used to generate highly specific polyclonal antibodies for development of a sandwich ELISA. The ELISA was used to quantify total plasma IgM in 602 Pacific herring captured in Prince William Sound and Sitka Sound, Alaska, USA. Plasma IgM concentrations ranged from 0.13 to $5.32 \mathrm{mg}$ $\mathrm{ml}^{-1}$. Using multiple stepwise regression analysis, plasma $\operatorname{lgM}$ was highly correlated $(\mathrm{p} \leq 0.01)$ with body length, Ichthyophonus hoferi infection. plasma albumin, plasma cholesterol, liver macrophage aggregates, and focal skin reddening. I. hoferi was the only organism significantly associated with plasma IgM. Gender, site, and season (spring vs fall) did not contribute to significant differences in plasma IgM. This study contributes to the understanding of the interaction of body size, plasma chemistries, and pathological changes upon circulating immunoglobulins in fish.
\end{abstract}

KEY WORDS: IgM - Immunoglobulin M. Pacific herring Clupea pallasi - Ichthyophonus hoferi ELISA Euglobulin - Plasma chemistry $\cdot$ Body length · Fish · Histopathology

\section{INTRODUCTION}

Total plasma immunoglobulin concentration may be a valuable indicator of general fish health. Circulating immunoglobulin levels in various species of fish vary with body size (Fuda et al. 1991, Sánchez et al. 1993, Estévez et al. 1995), temperature (Wilson \& Warr 1992), season (Yamaguchi et al. 1981, Zapata et al. 1992), and pathogenic organisms (Olesen \& Jørgensen 1986, Magnadottir \& Gudmundsdottir 1992); however, evaluation of the multiple interactive effects of body size, plasma chemistries and pathological changes upon circulating immunoglobulins in fish is lacking. Also, little data are available on plasma IgM in free-ranging fish and the effects of disease on plasma IgM levels in wild populations.

\footnotetext{
- Addressee for correspondence.
}

E-mail: gdmarty@ucdavis.edu
The population of Pacific herring Clupea pallasi in Prince William Sound, Alaska, USA, declined nearly $80 \%$ from a 20 yr peak biomass in fall 1992 to a $20 \mathrm{yr}$ low in spring 1994 (Marty et al. 1998). Viral hemorrhagic septicemia virus (VHSV) was isolated from pooled samples of these fish in 1993 (Meyers et al. 1994). Further study in 1994 confirmed the association of VHSV with disease, and Ichthyophonus hoferi was identified as a significant pathogen (Marty et al. 1998). The degree to which these 2 pathogens contributed to the population decline and the role of any precipitating factors have not been fully elucidated. Intensive study has not identified any direct link between the 1989 'Exxon Valdez' oil spill in Prince William Sound and the Pacific herring population decline.

Public and scientific interest in this wild Pacific herring population presented an unique opportunity to investigate the interaction of total plasma $\operatorname{IgM}$ with a variety of physical characteristics, plasma chemistries, histologic changes and pathogens recorded for these 
fish. We initiated this study with 3 main objectives: (1) purification and partial characterization of plasma IgM in Pacific herring; (2) development of a sandwich ELISA to quantify plasma IgM; and (3) identification of physical characteristics, plasma chemistry values, hematologic changes, and gross and microscopic pathologic changes that might be correlated with plasma IgM in free-ranging Pacific herring. In addition to sampling fish from Prince William Sound, sampling was done in Sitka Sound, Alaska, which was chosen as a reference site because it had an increasing Pacific herring population with an age composition similar to the population in Prince William Sound.

\section{MATERIALS AND METHODS}

Euglobulin purification, SDS-PAGE, western blotting, and sequence analysis. Pacific herring from Prince William Sound were caught in purse seines and held in $400 \mathrm{l}$ salt water. Blood was collected from the caudal vein into heparinized syringes. Samples from 100 fish were pooled and centrifuged at $3000 \times g$ for $10 \mathrm{~min}$. Plasma was harvested and held at $-20^{\circ} \mathrm{C}$ for transport to the laboratory, then stored at $-70^{\circ} \mathrm{C}$ until processed. The plasma was thawed and centrifuged at $4^{\circ} \mathrm{C}$ at $10000 \times g$ for $30 \mathrm{~min}$ to remove precipitated fibrin. The euglobulin was purified from plasma by extensive dialysis at $4^{\circ} \mathrm{C}$ against $5 \mathrm{mM}$ Tris- $\mathrm{HCL}, \mathrm{pH} 7.4$ (Dighiero et al. 1985, Partula \& Charlemagne 1993, Adkison et al. 1996). Protein content was determined via the Lowry (Folin-Ciocalteau) method (Lowry et al. 1951). The euglobulin fraction was analyzed by sodium dodecyl-sulfate polyacrylamide gel electrophoresis (SDS-PAGE) under reduced and nonreduced conditions with molecular weight standards including human IgM (Sigma). Proteins were electrophoretically transferred to polyvinylidene difluoride (PVDF) membranes (Immobilon-P, Millipore) and stained with Coomassie blue. Membranes were also incubated with specific polyclonal rabbit anti-herring euglobulin antibodies (described below). Due to amino terminal blocking, internal sequence analysis was carried out on the heavy chain portion after SDS-PAGE and electrophoretic transfer to PVDF membranes. Peptides were digested off the membrane with lysyl endopeptidase (Wako Bioproducts) as previously described (Fernandez et al. 1994). Fragments were purified on microbore HPLC (ABI Model 172) and isolated. Peptides were sequenced on an HPG1000 or ABI 470 sequence analyzer. Sequences were analyzed for homology with known peptides using the Kabatpro database and the BLASTP alignment tool (Altschul et al. 1990). Densitometry analysis (ImageQuant software; Molecular Dynamics, Inc.) was performed on Coomassie blue- stained gels to determine the percentage that the proposed heavy and light chain bands comprised of the total purified euglobulin fraction.

Polyclonal rabbit antibody. The herring euglobulin fraction was deglycosylated using a modification of a previously described protocol (Mattes \& Steiner 1978). Euglobulin $(2.5 \mathrm{mg}$ ) was resuspended in $0.04 \mathrm{M}$ sodium acetate buffer, pH 5.4, 0.1 M NaCl. An equal volume of $20 \mathrm{mM}$ sodium periodate in the same acetate buffer was added to the eluent and incubated at room temperature for $1 \mathrm{~h}$. Glycerol was added to $50 \%$ total volume and the mixture was dialyzed, using Spectrapor 2 tubing, against $4 \mathrm{l} \mathrm{PBS}, \mathrm{pH} 7.4$, overnight at $4{ }^{\circ} \mathrm{C}$. The dialyzed sample was centrifuged at $14000 \times g$ for 2 min. The supernatant was collected, divided into aliquots, and stored at -20 or $-70^{\circ} \mathrm{C}$. Protein concentration was determined via Lowry (Folin-Ciocalteau) method (Lowry et al. 1951).

A single male New Zealand White rabbit received an initial subcutaneous inoculation of $400 \mu \mathrm{g}$ deglycosylated euglobulin in complete Freund's adjuvant. A second subcutaneous inoculation of $400 \mu \mathrm{g}$ deglycosylated euglobulin in incomplete Freund's adjuvant was administered 4 wk later. Rabbit antibodies to herring euglobulin were detected by ELISA at a dilution of 1:51200 in serum collected $10 \mathrm{~d}$ after the second inoculation. The rabbit antiserum bound specifically with the euglobulin fraction when reacted with whole Pacific herring plasma on a western blot (data not shown). Polyclonal rabbit immunoglobulin (IgG) was purified by methods previously described (McKinney $\&$ Parkinson 1987). A portion of the purified antibody was biotinylated with NHS-LC-Biotin according to the manufacturer's instructions (Pierce).

Immunoprecipitation of Pacific herring and rainbow trout plasma was performed with the purified rabbit immunoglobulin. Pacific herring or rainbow trout plasma was incubated overnight at $4^{\circ} \mathrm{C}$ with rabbitanti-herring IgG diluted 1:100 (29 $\left.\mu \mathrm{g} \mathrm{ml} \mathrm{ml}^{-1}\right)$. The IgG-bound proteins were precipitated by addition of Protein G/Protein A agarose (Oncogene Research Products, Cambridge, MA). The precipitate was washed 2 times in lysis buffer (20 mM Tris, $\mathrm{pH} 7.5$, $150 \mathrm{mM} \mathrm{NaCl}, 1 \mathrm{mM}$ EDTA, $1 \mathrm{mM}$ EGTA [ethyleneglycol-bis-tetraacetic acid], 1\% Triton X-100, $2.5 \mathrm{mM}$ sodium pyrophosphate, $1 \mathrm{mM}$ B-glycerolphosphate, $1 \mathrm{mM} \mathrm{Na}_{3} \mathrm{VO}_{4}, 1 \mu \mathrm{g} \mathrm{m} \mathrm{l}^{-1}$ leupeptin) and 1 time in PBS, with centrifugation at $10000 \times g$ for $10 \mathrm{~min}$ after each wash. After reconstitution with PBS, precipitates were run on a $12 \%$ polyacrylamide gel and electrophoretically transferred to a PVDF membrane. The membrane was stained with Ponceau $\mathrm{S}$ to highlight all proteins in the reaction and then immunoblotted with biotinylated rabbit-anti-herring IgG. The membrane was blocked for $1 \mathrm{~h}$ in $5 \%$ nonfat dry milk in Tween TBS (TTBS: 
$50 \mathrm{mM}$ Tris, $\mathrm{pH} 8.0,1 \mathrm{mM}$ EDTA, $150 \mathrm{mM} \mathrm{NaCl}$ and $1 \mathrm{ml}$ Tween-20 per liter), then incubated with biotinylated rabbit-anti-herring IgG diluted 1:1000 $\left(3 \mu \mathrm{g} \mathrm{ml}^{-1}\right)$ for $1 \mathrm{~h}$ at room temperature. The membrane was washed in TTBS and incubated with streptavidin-alkaline phosphatase conjugate at a 1:2000 dilution at room temperature for $30 \mathrm{~min}$. The membrane was washed in TTBS and incubated with a chemiluminescent substrate (CDP-Star ${ }^{\text {TM }}$, Tropix, Inc., Bedford, MA) for $5 \mathrm{~min}$, drained, and exposed to X-ray film.

Development of a sandwich ELISA for detection of euglobulin. The ELISA was optimized as previously described (Case et al. 1983). To determine IgM concentrations in herring plasma samples, 96-well immunoassay plates (Falcon ${ }^{\circledR}$, Pro-bind ${ }^{\top M}$ ) were coated with rabbit anti-herring antibody $\left(50 \mu \mathrm{l} \mathrm{well}^{-1}\right)$ diluted 1:2500 $\left(1 \mu \mathrm{g} \mathrm{ml}^{-1}\right)$ in $50 \mathrm{mM}$ bicarbonate/carbonate buffer, $\mathrm{pH} 9.6$, and incubated overnight at $4^{\circ} \mathrm{C}$ or $2 \mathrm{~h}$ at $37^{\circ} \mathrm{C}$. Following incubation, plates were washed 5 times with TTBS and shaken vigorously to remove excess fluid. Wells were blocked with $5 \%$ nonfat dry milk in TTBS and incubated at $37^{\circ} \mathrm{C}$ for $60 \mathrm{~min}$. Plates were then washed 5 times. Fifty $\mu \mathrm{l}$ of test sample were added to each well and incubated at $37^{\circ} \mathrm{C}$ for $60 \mathrm{~min}$. Plates were again washed 5 times, followed by addition of $50 \mu$ well $^{-1}$ of biotinylated rabbit anti-herring antibody diluted 1:800 (3.75 $\left.\mu \mathrm{g} \mathrm{m} \mathrm{m}^{-1}\right)$ in blocking buffer. After a $60 \mathrm{~min}$ incubation at $37^{\circ} \mathrm{C}$, the plates were again washed, followed by addition of $50 \mu \mathrm{l}$ well ${ }^{-1}$ peroxidase-streptavidin diluted 1:1000 in blocking buffer. After a $30 \mathrm{~min}$ incubation at $37^{\circ} \mathrm{C}$, plates were washed 9 times. The TMB substrate solution was added $\left(100 \mu \mathrm{l}\right.$ well $\left.^{-1}\right)$ and the plates incubated for 20 to $40 \mathrm{~min}$ at $37^{\circ} \mathrm{C}$. The reaction was stopped with the addition of $50 \mu \mathrm{l}$ well ${ }^{-1} 1 \mathrm{M} \mathrm{H}_{2} \mathrm{SO}_{4}$. Each plate contained reference blanks and standard curves in triplicate. The standard curve was constructed using serial dilutions of herring euglobulin of known protein concentration. Plates were read at $450 \mathrm{~nm}$ on a Ceres 900 Hdi plate reader (Bio-Tek) and interpreted with Kineti $\mathrm{Calc}^{\mathrm{rm}}$ version 2.12 software using end point curvilinear regression.

Field study collections. Pacific herring in spawning condition were sampled in the spring of 1995 in 2 groups: (1) 240 fish from Sitka Sound (used as a reference site) and (2) 180 fish from Prince William Sound (PWS). The PWS sample was smaller due to fewer spawning fish captured. In the fall of 1995, 130 fish were sampled from PWS. All fish were captured by purse seine and held no longer than $4 \mathrm{~h}$ in ambient temperature salt water before necropsy. The water temperature was 4 to $5^{\circ} \mathrm{C}$ at the time of capture in the spring and 6 to $10^{\circ} \mathrm{C}$ in the fall; water temperature was not rechecked during the holding period. All fish were deeply anesthetized with tricaine methane sulfonate
(Finquel ${ }^{\mathrm{rM}}$ ) and subjected to complete necropsy, which included determination of weight, standard length, and age (from scale annuli). Blood samples were obtained from the caudal vein at the beginning of the necropsy, effectively exsanguinating the fish. Plasma was harvested and aliquots frozen for (1) later analysis on a Monarch plus analyzer (Instrumentation Laboratories, Lexington, MA, USA) calibrated and run at $25^{\circ} \mathrm{C}$ to quantify total plasma protein, albumin, $\mathrm{CO}_{2}$, calcium, cholesterol, glucose, phosphorus, total bilirubin, alkaline phosphatase, alanine aminotransferase, aspartate animotransferase, creatine phosphokinase, gamma glutamyltransferase, sodium, potassium, and chloride, and (2) IgM quantification. Samples of gill, liver, gonad, spleen, trunk kidney, gastrointestinal tract, heart, skin, skeletal muscle, and brain were fixed in $10 \%$ buffered formalin for histopathology. Herring worms (Anisakidae) present in the peritoneal cavity were also counted. Head kidney and spleen from each fish were pooled and shipped on ice to the Alaska Department of Fish and Game Fish Pathology Laboratory (Juneau, AK, USA) for viral isolation; skin lesions, if present, were submitted separately. Propagation of 1 cell line (EPC, epithelioma papillosum cyprini cells), media formulation, and tissue preparation for inoculation was performed as previously described (Meyers et al. 1994). Propagation of a second cell line (PHE, Pacific herring embryo) was similar except media lacked tryptose phosphate broth. Swabs of kidney from fish with severe external lesions were inoculated onto trypticase soy agar and marine agar. Plates were incubated at $23^{\circ} \mathrm{C}$ for at least $3 \mathrm{~d}$. No viral or bacterial pathogens were isolated from any of the fish.

Formalin-fixed tissues were processed with standard methods for paraffin embedding, sectioned at $5 \mu \mathrm{m}$, and stained with hematoxylin and eosin. Tissues were read in ascending numerical order using random histopathology numbers assigned to each fish. Lesions were scored, using a 4 point scale, as none (0), mild (1), moderate (2), or severe (3). Ranking of lesions was the same as previously described (Marty et al. 1998). Ichthyophonus hoferi infection was diagnosed by identification of the organisms in tissue sections. After all organs were examined and lesions scored, data were rearranged by necropsy number and subjected to statistical analysis.

Statistical analysis. The association of categorical variables (e.g. none, mild, moderate, and severe) with continuous variables (e.g. $\ln$ IgM concentrations) was determined using 1-way analysis of variance (1-way ANOVA). Category-specific means and standard errors were calculated for each continuous variable and compared using Tukey's Studentized range method. Levene's test was used to evaluate the homogeneity of variance assumption for the ANOVA. Most 
analyses were run separately for spawning fish from Sitka Sound and PWS, and fish collected in the fall from PWS. To measure the strength of the linear relationship between 2 continuous variables, the correlation coefficient $r$ was calculated.

Multiple stepwise regression analysis was used to identify a subset of variables that were predictive of IgM (log transformed). Those variables with the strongest predictive values were selected for further stepwise analysis. It was necessary to run 2 stepwise analyses in order to minimize the number of cases that were deleted due to missing values. In this way, only cases missing values for 1 or more of the variables strongly predictive of IgM were deleted. For a full report of variables, see Marty et al. 1998. For all analyses, comparisons were considered significant when $\mathrm{p} \leq$ 0.05 . Use of the term 'prevalence' refers to the sample prevalence.

\section{RESULTS}

\section{Euglobulin characterization and sequence data}

The purified euglobulin fraction consisted primarily of protein with a molecular weight comparable to purified human IgM (Fig. 1). Under reducing conditions, the herring immunoglobulin was comprised of a $79 \mathrm{kD}$ heavy chain and 3 light chains ranging from 25 to $27.5 \mathrm{kD}$ (Fig. 2). With densitometry analysis, 98\% of the reduced euglobulin fraction consisted of heavy and light chain bands. Two independent internal heavy chain fragments were sequenced. In the first fragment, 15 residues were sequenced, with poor yield at cycles 6 and 15. The residue at position 6 was either a cysteine or a tryptophan, and the residue at position 15 was most likely a lysine. For the second fragment, 11 residues were sequenced. The 15 amino acid sequence showed significant homology with several IgM heavy chain constant regions (Table 1). No significant matches were made with the 11 amino acid peptide sequence.
Fig. 1. Clupea pallasi SDS-PAGE analysis of nonreduced Pacific herring putative IgM (lane a), molecular weight markers (lane b) and human IgM for comparison (lane c). 8 to $25 \%$ gradient gel
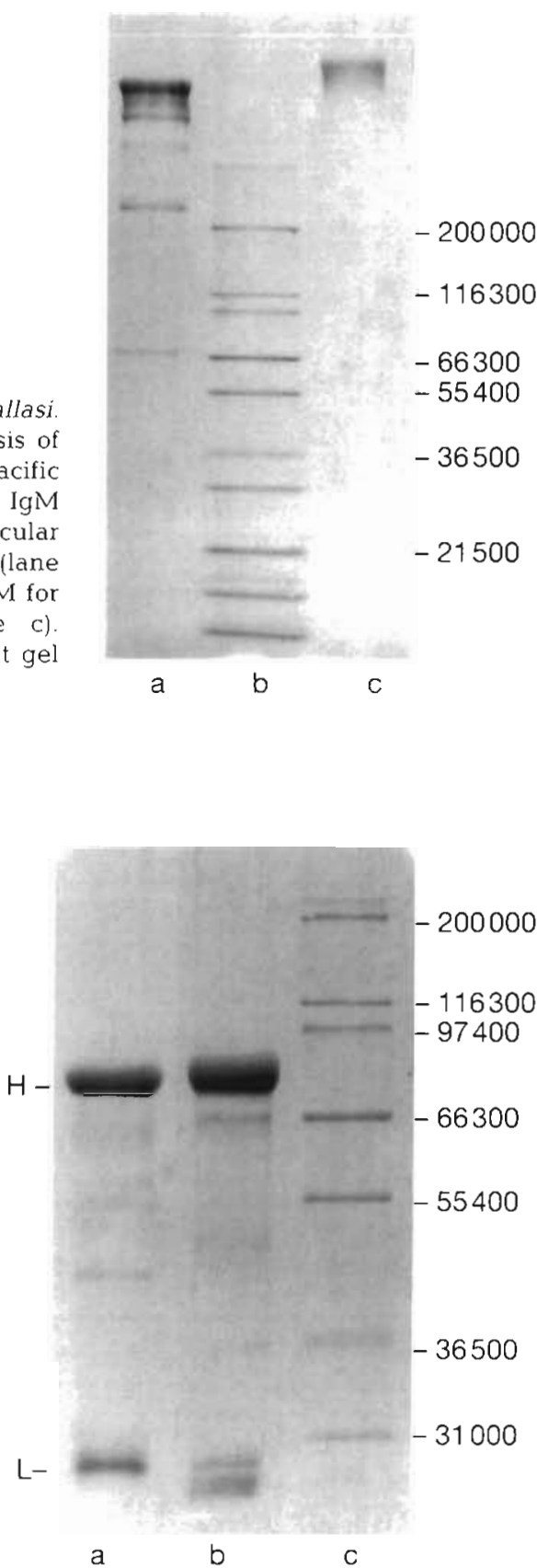

Table 1. Cluped pallasi. Comparison of amino acid sequences of an internal fragment of Pacific herring IgM with heavy chain sequences from different species using the Kabatpro database and BLASTP alignment tool. The underlined tryptophan and lysine were not completely specified. X: no amino acid match. Database accession numbers are given. Amino acid positions of the matching sequences within the heavy chains are included

\begin{tabular}{|c|c|c|c|c|c|c|c|c|c|c|c|c|c|c|c|c|}
\hline \multirow{2}{*}{$\frac{\text { Species }}{\text { Pacific herring }}$} & \multirow[t]{2}{*}{ Accession no. } & \multicolumn{15}{|c|}{ Amino acid sequence } \\
\hline & & $E$ & $\mathrm{~V}$ & $\mathrm{~F}$ & V & $\mathrm{S}$ & $\underline{W}$ & $\mathrm{~L}$ & A & $\mathrm{D}$ & $\mathrm{D}$ & $\mathrm{E}$ & $\mathrm{P}$ & $\mathrm{V}$ & A & $\underline{\mathrm{K}}$ \\
\hline Atlantic salmon, amino acids 350 to 362 & KADBID 013655 & $\mathrm{E}$ & V & L & V & A & W & $\mathrm{L}$ & I & $\mathrm{D}$ & $\mathrm{D}$ & E & $\mathrm{P}$ & $\mathrm{V}$ & $\mathrm{x}$ & $\mathrm{x}$ \\
\hline Rainbow trout, amino acids 349 to 361 & KADBID 013652 & $\mathrm{D}$ & $\mathrm{V}$ & $\mathrm{L}$ & $\mathrm{V}$ & A & W & $\mathrm{L}$ & $\mathrm{V}$ & $\mathrm{D}$ & $\mathrm{D}$ & $\mathrm{E}$ & $\mathrm{P}$ & $\mathrm{V}$ & $\mathrm{X}$ & $x$ \\
\hline Elops, amino acids 342 to 354 & KADBID 013659 & Q & $\mathrm{V}$ & $\mathrm{L}$ & I & $\mathrm{S}$ & W & $\mathrm{L}$ & $\mathrm{V}$ & $\mathrm{D}$ & $\mathrm{D}$ & $\mathrm{Q}$ & $P$ & V & $\mathrm{X}$ & $\mathrm{X}$ \\
\hline Sheep, amino acids 362 to 375 & KADBID 013636 & $\mathrm{D}$ & V & $F$ & $\mathrm{~V}$ & $Q$ & W & $\mathrm{L}$ & $Q$ & $\mathrm{~K}$ & $G$ & $E$ & $\mathrm{P}$ & V & $\mathrm{A}$ & $x$ \\
\hline
\end{tabular}


Fig. 3. Clupea pallasi. Western blot of Pacific herring and rainbow trout proteins precipitated with rabbitanti-Pacific herring euglobulin antibody. Lanes a-d: precipitated proteins stained with Ponseau $S_{i}$ lanes $a^{\prime}-d^{\prime}$ the same blot probed with biotinylated rabbit-anti-herring $\lg M$ antibody. Lanes: a and $a^{\prime}$, Pacific herring plasma; $b$ and $b^{\prime}$, rainbow trout plasma; $c$ and $c^{\prime}$, rabbitanti-Pacific herring $\lg M$ antibody alone; $\mathrm{d}$ and $\mathrm{d}$ ', Protein G/Protein A agarose alone. Molecular weight markers are located in the far left lane. The immunoblot has been overexposed to demonstrate all reactive protein bands

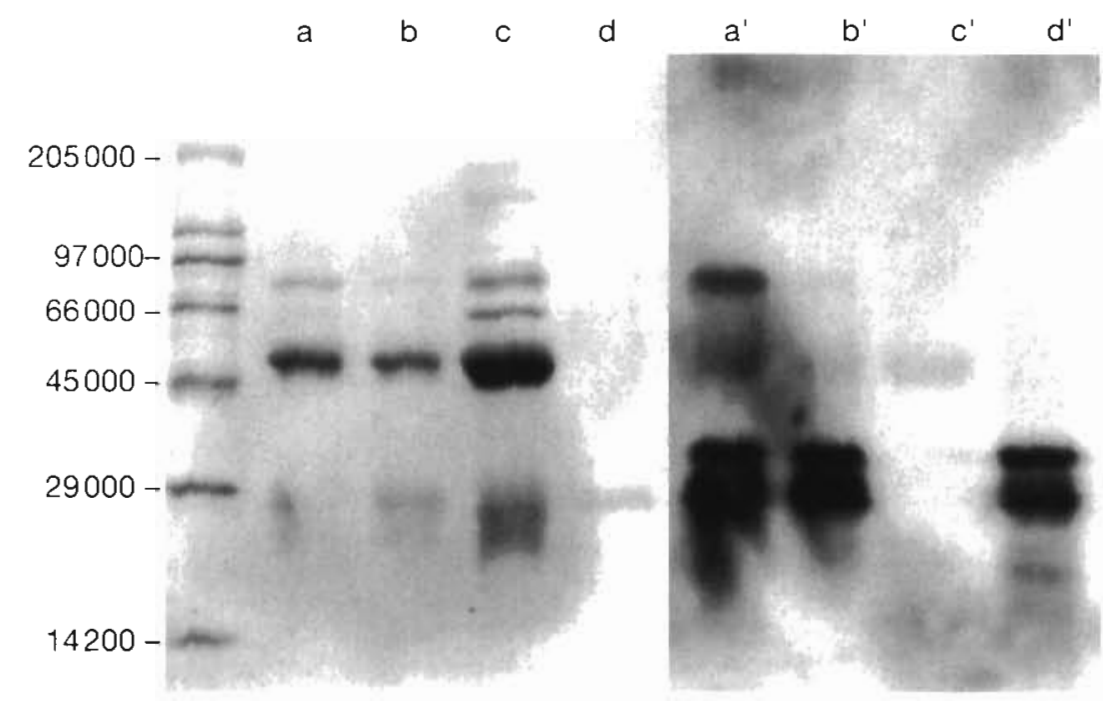

\section{Specificity of the rabbit antibody}

Immunoprecipitation of Pacific herring and rainbow trout plasma with the rabbit-anti-herring immunoglobulin demonstrated specificity of the rabbit IgG for a single protein in Pacific herring plasma with an apparent molecular weight consistent with putative $\operatorname{IgM}$ heavy chain (Fig. 3, lane $\mathrm{a}^{\prime}$ ). Because protein reagents of the immunoprecipitation reactions appeared in the blots, 2 lanes (Fig 3, lanes $\mathrm{c} / \mathrm{c}^{\prime}$ and $\mathrm{d} / \mathrm{d}^{\prime}$ ) were run as controls to demonstrate where the rabbit IgG and the Protein G/Protein A agarose bands are located, allowing differentiation from precipitated plasma components. The Ponceaus S stain (left half, Fig. 3) demonstrates a very strong band in the rabbit IgG (Fig. 3, lane c) near $50 \mathrm{kD}$ representing rabbit Ig heavy chains. Bands of the same molecular weight in lanes $a$ and $b$ are interpreted as rabbit IgG heavy chains from the immunoprecipitation reaction. None of the rabbit protein reacted with biotinylated rabbit-anti-herring IgG (Fig. 3, lane $c^{\prime}$ ). The biotinylated antibody bound strongly to components of the Protein G/Protein A agarose (Fig. 3, lane d'). Corresponding bands in lanes $a^{\prime}$ and $b^{\prime}$ are also interpreted as Protein G/Protein A agarose components from the immunoprecipitation reaction. The strong reaction of the rabbit $\operatorname{IgG}$ with Protein G/Protein A agarose components in lanes a' and $b^{\prime}$ may obscure bands in the lower molecular weight regions, where light chains are expected.

\section{ELISA parameters}

The intraplate coefficient of variation (same plate, same day, same sample: 5 standard dilutions run in triplicate on a total of 60 plates) for the ELISA ranged from 0.3 to $36.3 \%$, with a mean of $10.9 \%$. The interplate coefficient of variation (different plate, different day, same sample: 9 samples run in triplicate on 3 different days) ranged from 3.7 to $32.6 \%$, with a mean of $16.1 \%$. The ELISA detected IgM concentrations as low as $0.039 \mu \mathrm{g} \mathrm{ml}^{-1}$ and the test can be performed in 4 to $6 \mathrm{~h}$.

\section{IgM levels in Pacific herring}

Plasma IgM levels ranged from 0.13 to $5.32 \mathrm{mg} \mathrm{ml}^{-1}$ for all samples tested $(n=602)$. IgM as a percentage of total protein ranged from 0.5 to $20.4 \%$, with an average of $2.9 \%$ in Ichthyophonus hoferi-negative fish and $4.9 \%$ in $I$. hoferi-positive fish. Using univariate analysis, plasma IgM increased significantly as lesion scores increased for $I$. hoferi infection. For example, plasma IgM significantly increased with increasing severity of I. hoferi lesions in the heart (Fig. 4). In addition to $I$.

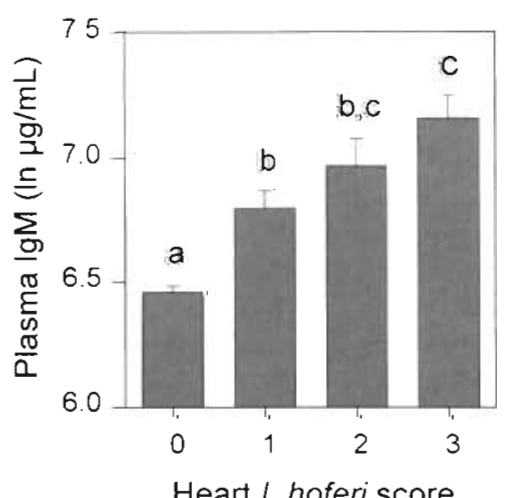

Fig. 4. Clupea pallasi. Relationship of heart Ichthyophonus hoferi lesion score $(0$, none; 1 , mild; 2 , moderate; 3 , severe $)$ with ln plasma IgM. Bars with different letter designations are significantly different (Tukey's multiple comparison procedure, $p \leq 0.05$ ) 
Table 2. Clupea pallasi. Histologic lesions associated with increasing plasma IgM. Significant trends were based on rank order of mean responses for fish groups classified by lesion scores. Compared to fish with the lowest lesion score, mean response for the fish group with the highest lesion score was significantly higher (ANOVA, $p \leq 0.05$ ). $\downarrow$ : downward trend in IgM. PWS: Prince William Sound. SS: Sitka Sound

\begin{tabular}{|llr|}
\hline Histologic finding & Population & $\begin{array}{c}\text { Significant } \\
\text { trend in IgM } \\
\text { (p-value) }\end{array}$ \\
\hline Ichthyophonus hoferi & & \\
Heart, kidney, liver, spleen & PWS spawning & $\leq 0.001$ \\
& SS spawning & $\leq 0.001$ \\
Skin/skeletal muscle & PWS fall & $\leq 0.001$ \\
& PWS spawning & $\leq 0.001$ \\
Gill arch inflammation & SS spawning & $\leq 0.001$ \\
Meningoencephalitis & PWS fall & 0.005 \\
Epicarditis & PWS spawning & 0.005 \\
Steatitis, mesenteric & SS spawning & 0.036 \\
& PWS spawning & 0.021 \\
Trunk kidney & SS spawning & 0.001 \\
hematopoietic cells & PWS fall & 0.015 \\
Pigmented macrophage aggregates & SS spawning & $\leq 0.001$ \\
Liver & PWS fall & $\leq 0.001$ \\
& SS spawning & $\leq 0.001$ \\
Spleen & PWS fall & 0.031 \\
& SS spawning & $\leq 0.001$ \\
Splenic vascular congestion & PWS spawning & 0.043 \\
Submucosal gastritis & PWS fall & 0.017 \\
Granulomatous inflammation, liver & PWS spawning & 0.026 \\
Hepatic lipidosis & SS spawning & 0.016 \\
& SS spawning & 0.013 \\
& & $0.013 \downarrow$ \\
\hline
\end{tabular}

\section{DISCUSSION}

We have shown that Pacific herring immunoglobulin is an IgM-like molecule with a native molecular weight similar to that of human IgM. This finding is in agreement with previous reports of IgM in fish (Kobayashi et al. 1982, Estévez et al. 1993), and with the tetrameric nature of teleost IgM (Wilson \& Warr 1992, Rombout et al. 1993). Previously reported values for heavy and light chains in a variety of fish species are all in the range of 70 to $79 \mathrm{kD}$ for heavy chains and 23 to $30 \mathrm{kD}$ for light chains: Cyprinus carpio (Marchalonis 1971, Koumans-van Diepen et al. 1995), Oncorhynchus keta (Kobayashí et al. 1982), Carassius auratus (Marchalonis 1971), Scophthalmus maximus (Esétvez et al. 1993), Acipenser transmontanus (Adkison et al. 1996), and Acipenser baeri (Partula \& Charlemagne 1993).

This is the first report of plasma IgM levels in Pacific herring. Serum IgM concentrations have been reported for several other species: Oncorhynchus mykiss, 0.6 to $9.3 \mathrm{mg} \mathrm{m}^{-1}$ (Sánchez et al. 1993) and $3.3 \mathrm{mg} \mathrm{m}^{-1}$ (Olesen \& Jørgensen 1986); Salmo trutta, $7.3 \mathrm{mg} \mathrm{ml}^{-1}$ (Ingram \& Alexander 1979); Oncorhynchus keta, 0.63 to $0.72 \mathrm{mg} \mathrm{m}^{-1}$ (Kobayashi et al. 1982); and Scophthalmus maximus, 3.35 to $11.14 \mathrm{mg} \mathrm{ml}^{-1}$ (Estévez et al. 1995). The IgM component of total serum protein in fish has been reported as $6.4 \%$ (Mochida et al. 1994), $10 \%$ (Ingram \& Alexander 1979), and 7.5 to

hoferi infection, a variety of nonspecific histologic lesions were also significantly associated with increasing plasma IgM (Table 2). Hepatic lipidosis was the only variable associated with a decreasing trend in plasma IgM. Finally, still using univariate analysis, several variables were significantly correlated with increases in plasma IgM (Table 3): length, weight and age, as well as the plasma chemistries alkaline phosphatase, cholesterol, plasma protein, and albumin.

Using multiple stepwise regression, body length, heart Ichthyophonus hoferi score, and plasma albumin were the factors most strongly correlated with plasma IgM (Table 4). In the stepwise regression model, these 3 variables accounted for $29 \%$ of the variability in plasma IgM.

Eight parasites occurred at a prevalence of 10 to $90 \%$ (Marty et al. 1998), but none were significantly associated with IgM levels. Also, gender, site, and season (spring vs fall) did not contribute to significant differences in plasma IgM.
$18 \%$ (Estévez et al. 1995). Due to variation among different fish species, variable methods of total protein determination, and possible interaction of age as well as infectious disease status on $\operatorname{Ig} M$, this parameter may vary widely between studies.

Table 3. Clupea pallasi. Correlation coefficients (r) for continuous variables significantly correlated with $\ln \operatorname{IgM}$, univariate analysis $(\mathbf{p} \leq 0.05)$. PWS: Prince William Sound. SS: Sitka Sound

\begin{tabular}{|c|c|c|c|}
\hline Variable & $\begin{array}{c}\text { PWS spring } \\
\mathrm{n} \approx 177\end{array}$ & $\begin{array}{l}\text { SS spring } \\
\mathrm{n}=234\end{array}$ & $\begin{array}{c}\text { PWS fall } \\
n=128\end{array}$ \\
\hline Length (mm) & 0.262 & 0.206 & 0.377 \\
\hline Weight (g) & 0.210 & 0.174 & 0.414 \\
\hline Age $(y r)$ & 0.264 & 0.227 & 0.357 \\
\hline Alkaline phosphatase $\left(\mathrm{Ul}^{-1}\right)$ & 1) 0.196 & 0.136 & 0.204 \\
\hline Cholesterol $\left(\mathrm{mg} \mathrm{dl}^{-1}\right)$ & 0.182 & 0.179 & 0.226 \\
\hline Plasma protein $\left(\mathrm{g} \mathrm{dl}^{-1}\right)$ & 0.361 & 0.221 & 0.478 \\
\hline Albumin $\left(\mathrm{g} \mathrm{dl}^{-1}\right)$ & 0.362 & 0.247 & 0.416 \\
\hline
\end{tabular}


Table 4. Clupea pallasi. Significant predictors of IgM concentration ( $p \leq$ $0.05)$ generated using multiple stepwise regression. All parameter estimates are positive except for focal skin reddening and hold time ( $\downarrow$ : negative correlation coefficient). Scored variables were classified as none $(0)$, mild (1), moderate (2), or severe (3)

\begin{tabular}{|lccc|}
\hline Variable & Partial $\mathrm{r}^{2}$ & Model $\mathrm{r}^{2}$ & $\mathrm{p}$ \\
\hline Length (mm) & 0.156 & 0.156 & 0.0001 \\
Heart IChthyophonus hoferi (score) & 0.076 & 0.232 & 0.0001 \\
Albumin (g dl ${ }^{-1}$ ) & 0.058 & 0.290 & 0.0001 \\
Cholesterol (mg dl ${ }^{-1}$ ) & 0.015 & 0.305 & 0.0004 \\
Liver macrophage aggregates (score) & 0.012 & 0.317 & 0.0017 \\
Focal skin reddening (score) & $0.009 \downarrow$ & 0.326 & 0.0053 \\
Kidney hematopoietic cells (score) & 0.007 & 0.333 & 0.0125 \\
Hold time (min) & $0.006 \downarrow$ & 0.338 & 0.0286 \\
\hline
\end{tabular}

Serum or plasma chemistry studies in Pacific herring are scarce (Márquez 1976. Marty et al. 1998); thus, interpretation of chemistry values is difficult. The multiple regression analysis identified the collinear relationship of albumin and total protein. The positive association of albumin and total protein with IgM may be related to fasting of herring in the weeks before spawning. Decreases in plasma proteins have been reported in fasting fish (Navarro \& Gutierrez 1995), with albumin being the first plasma protein to be depleted. Gamma globulins are reportedly not utilized during fasting, but it is possible that gamma globulin produc-

The range of $\operatorname{Ig} M$ concentrations in Pacific herring could be due to a combination of factors. IgM levels were most strongly correlated with body length. Body length, in turn, was highly correlated to body weight and age (Marty et al. 1998). In our regression analysis, body length was a better predictor of IgM than age or body weight. This finding may be due to 2 factors: (1) body length was a better continuous variable than age, and (2) among actively spawning fish, gonad weight (comprising up to $30 \%$ of body weight in prespawning fish) was highly variable because some fish had spawned and thus had empty gonads while others were yet to spawn and still had full gonads.

Independent of fish size, total plasma IgM was strongly and positively related to Ichthyophonus hoferi infection. Previous studies have shown that total immunoglobulin levels in fish increase with natural exposure to a pathogen (Magnadottir \& Gudmundsdottir 1992), and I. hoferi has been previously identified as a significant pathogen in Atlantic herring Clupea harengus (Daniel 1933) and Pacific herring (Kocan et al. 1999). Also, specific immune responses have been demonstrated in fish in response to $I$. hoferi (McVicar \& McLay 1985). Due to the chronic granulomatous inflammatory response to $I$. hoferi in Pacific herring (Elston et al. 1997, Marty et al. 1998), elevated total IgM concentrations in infected fish could reflect chronic exposure to $I$. hoferi antigens. The increase in IgM concentrations with increasing severity of $I$. hoferi infection in this study is consistent with previous reports that precipitating antibodies to $I$. hoferi are not protective against infection in other fish species (McVicar \& McLay 1985). In our study, the proportion of total plasma IgM elevation due to a specific antibody response was not determined.

After the effects of body size and Ichthyophonus hoferi infection were accounted for, it is likely that nutritional status reflected by plasma albumin, total protein, and cholesterol had an impact on plasma IgM. tion may be diminished in fasting fish. Decreases in plasma cholesterol have been reported in a variety of teleost species when fasting occurred in conjunction with spawning (McDonald \& Milligan 1992). Hepatic lipidosis, which may reflect mobilization of body fat stores during fasting, was also significantly associated with decreasing IgM in Sitka Sound fish (Table 2). Plasma IgM may drop in females coincident with spawning due to incorporation of $\operatorname{IgM}$ into the eggs (Castillo et al. 1993, Takemura \& Takano 1997); however, this incorporation is likely to occur at the level of nanograms of IgM per gram of egg (Takemura \& Takano 1997), thus not significantly contributing to changes in circulating IgM. The positive correlation of plasma alkaline phosphatase with IgM is unexplained.

Unidentified inflammatory processes or tissue damage may have contributed significantly to increased plasma IgM, as reflected by the positive correlation of liver macrophage aggregates with IgM independent of age and Ichthyophonus hoferi infection. The pigmented macrophage aggregates of fish are repositories of pigment that likely reflect previous tissue injury with accumulation of membrane breakdown products. These aggregates may also represent primitive germinal centers (Agius 1985). The strong association of kidney hematopoiesis with increased IgM likely reflects a general increase in immune responsiveness because the kidney is the primary hematopoietic tissue in most teleost fishes. Studies using molecular markers to identify specific cell lineages in fish may help clarify processes in hematopoietic tissue in response to pathogens.

Focal skin reddening, negatively correlated with IgM, may be a nonspecific clinical sign associated with systemic disease. Possibly, some types of focal skin reddening reflected processes in which humoral immunity was suppressed.

The negative correlation of holding time to plasma IgM concentrations may be explained by gradual 
recovery from the initial stress of capture. Within a few minutes after acute stress due to capture, catecholamine and cortisol release and muscle lactacidosis result in elevated intracellular osmolarity, which causes a fluid shift from the circulation to the intracellular compartment (McDonald \& Milligan 1992). This fluid shift results in increased concentrations of plasma proteins, including IgM. Over time, if the stress level is decreased, the fluid shift will reverse and protein concentrations return to normal.

The association of $\operatorname{IgM}$ with inflammatory lesions such as gill arch inflammation and meningoencephalitis seen in the univariate, but not the multivariate, analysis may be due to several factors. First, the association may be related to age, because older fish have higher IgM values and these older fish may be exposed to more inflammatory agents as a function of time. Secondly, since IgM was correlated with Ichthyophonus hoferi infection, some fish with $I$. hofer may have suffered from other opportunistic infections that were reflected in the nonspecific inflammation.

Although effects of season on IgM have been reported (Zapata et al. 1992), no seasonal effect on IgM was noted in this study. It is possible that seasonal variations would have been detected if sampling had been done in mid-summer or mid-winter. Antibody responses in fish are generally affected by temperature: fish tend to produce better responses at warmer than colder temperatures (Wilson \& Warr 1992). Lower IgM serum concentrations were reported in rainbow trout held at $7^{\circ} \mathrm{C}$ compared to $19^{\circ} \mathrm{C}$ (Sánchez et al. 1993). Surface water temperature in this study ranged from 4 to $5^{\circ} \mathrm{C}$ during spring sampling and from 6 to $10^{\circ} \mathrm{C}$ in the fall. Although the surface water temperature varies with season, the herring stay in deeper water in the fall; thus, fish collected in the fall may actually be at a temperature similar to that of shallow waters inhabited in the spring.

In this study, we have partially characterized Pacific herring IgM, developed a sensitive ELISA to quantify plasma IgM, and determined a range for total plasma IgM values in a wild fish population. Ichthyophonus hoferi is a pathogenic organism whose presence is significantly correlated with Pacific herring plasma IgM. Also, physical characteristics such as body length, as well as plasma chemistry values and histologic changes, are significantly associated with plasma IgM. Finally, we found no evidence that the population decline in Prince William Sound was associated with changes in plasma IgM levels. Further study is needed to determine concentrations of specific $I$. hoferi antibodies in healthy and infected fish and to evaluate cellmediated immunity.
Acknowledgements. The authors thank Young Moo Lee and Jack Presley for amino acid sequencing, Neil Willits for multiple regression analysis, the Alaska Department of Fish and Game for assistance with herring sampling, and Nancy $J$ Rooijakkers for technical assistance. The research described in this paper was supported by U.S. National Science Foundation award no. 9871982 and the 'Exxon Valdez' Oil Spill Trustee Council through a contract with the Alaska Department of Fish and Game; however, the findings and conclusions presented by the authors are their own and do not necessarily reflect the views or position of the Trustee Council.

\section{LITERATURE CITED}

Adkison MA, Basurco B, Hedrick RP (1996) Humoral immunoglobulins of the white sturgeon, Acipenser transmontanus: partial characterization of and recognition with monoclonal antibodies. Dev Comp Immunol 20:285-298

Agius C (1985) The melano-macrophage centres of fish. In: Manning MJ, Tatner MF (eds) Fish immunology. Academic Press, London, p 85-105

Altschul SF, Gish W, Miller W, Myers EW, Lipman DJ (1990) Basic local alignment search tool. J Mol Biol 215:403-410

Case JT, Ardans AA, Bolton DC, Reynolds BJ (1983) Optimization of parameters for detecting antibodies against infectious bronchitis virus using an enzyme linked immunosorbent assay: temporal response to vaccination and challenge with live virus. Avian Dis 27:196-210

Castillo A, Sánchez C, Dominguez J, Kaattari SL, Villena AJ (1993) Ontogeny of IgM and IgM-bearing cells in rainbow trout. Dev Comp Immunol 17:419-424

Daniel GE (1933) Studies on Ichthyophonus hoferi, a parasitic fungus of the herring. Clupea harengus. II. The gross and microscopic lesions produced by the parasite. Am J Hyg Baltimore 17:491-501

Dighiero G, Lymberi P, Holmberg D, Lundquist I, Coutinho A, Avrameas S (1985) High frequency of natural autoantibodies in normal newborn mice. J Immunol 134:765-771

EIston RA, Drum AS, Pearson WH, Parker K (1997) Health and condition of Pacific herring Clupea pallasi from Prince William Sound, Alaska, 1994. Dis Aquat Org 31:109-126

Estévez J, Leiro J, Sanmartín ML, Ubeira FM (1993) Isolation and partial characterization of turbot (Scophthalmus maximus) immunoglobulins. Comp Biochem Physiol A Comp Physiol 105A:275-281

Estévez J, Leiro J, Santamarina MT, Ubeira FM (1995) A sandwich immunoassay to quantify low levels of turbot (Scophthalmus maximus) immunoglobulins. Vet Immunol Immunopathol 45:165-174

Fernandez J, Andrews L. Mische SM (1994) A one-step enzymatic digestion procedure for PVDF-bound proteins that does not require PVP-40. In: Crabbs JW (ed) Techniques in protein chemistry V. Academic Press, San Diego, p $215-222$

Fuda $H$, Soyano $K$, Yamazaki F, Hara A (1991) Serum immunoglobulin $M$ (IgM) during early development of masu salmon (Oncorhynchus masou). Comp Biochem Physiol A Comp Physiol 99:637-643

Ingram GA, Alexander JB (1979) The immunoglobulin of the brown trout, Salmo trutta and its concentration in the serum of antigen-stimulated and non-stimulated fish. J Fish Biol 14:249-260

Kobayashi K, Hara A, Takano K, Hirai H (1982) Studies on subunit components of immunoglobulin $M$ from a bony fish, the chum salmon (Oncorhynchus keta). Mol Immunol 19:95-103 
Kocan RM, Hershberger P, Mehl T, Elder N, Bradley M, Wildermuth D, Stick K (1999) Pathogenicity of Ichthyophonus hoferi for laboratory-reared Pacific herring Clupea pallasi and its early appearance in wild Puget Sound herring. Dis Aquat Org 35:23-29

Koumans-van Diepen JCE, Egberts E, Peixoto BR, Taverne N, Rombout JHWM (1995) B cell and immunoglobulin heterogeneity in carp (Cyprinus carpio L.); an immuno(cyto)chemical study. Dev Comp Immunol 19:97-108

Lowry OH, Rosebrough NJ, Farr AL, Randall RJ (1951) Protein measurement with the Folin phenol reagent. J Biol Chem 193:265-275

Magnadottir B, Gudmundsdottir BK (1992) A comparison of total and specific immunoglobulin levels in healthy Atlantic salmon (Salmo salar L.) and in salmon naturally infected with Aeromonas salmonicida subsp. achromogenes. Vet Immunol Immunopathol 32:179-189

Marchalonis JJ (1971) Isolation and partial characterization of immunoglobulins of goldfish (Carassius auratus) and carp (Cyprinus carpio). Immunology 20:161-173

Márquez ED (1976) A comparison of glutamic-oxalacetate transaminase, lactate dehydrogenase, $\alpha$-hydroxybutyrate dehydrogenase, and creatine phosphokinase activities in non-spawning, pre-spawning, and spawning pink salmon. Comp Biochem Physiol 54B:121-123

Marty GD, Freiberg EF, Meyers TR, Wilcock J, Farver TB, Hinton DE (1998) Viral hemorrhagic septicemia virus, Ichthyophonus hoferi, and other causes of morbidity in Pacific herring Clupea pallasi spawning in Prince William Sound, Alaska, USA. Dis Aquat Org 32:15-40

Mattes MJ, Steiner LA (1978) Antisera to frog immunoglobulins cross-react with a periodate-sensitive cell surface determinant. Nature 273:761-763

McDonald DG, Milligan CL (1992) Chemical properties of the blood. In: Hoar WS, Randall DJ, Farrell AP (eds) Fish physiology, Vol XIIb, The cardiovascular system. Academic Press, San Diego, p 55-133

McKinney MM, Parkinson A (1987) A simple, non-chromatographic procedure to purify immunoglobulins from serum and ascites fluid. J Immunol Methods 96:271-278

McVicar AH, McLay HA (1985) Tissue response of plaice, haddock, and rainbow trout to the systemic fungus

Editorial responsibility: Donald Evans,

Athens, Georgia, USA
Ichthyophonus. In: Ellis AE (ed) Fish and shellfish pathology. Academic Press, London, p 329-347

Meyers TR, Short S, Lipson K, Batts WN, Winton JR, Wilcock J, Brown E (1994) Association of viral hemorrhagic septicemia virus with epizootic hemorrhages of the skin in Pacific herring Clupea harengus pallasi from Prince William Sound and Kodiak Island, Alaska, USA. Dis Aquat Org 19:27-37

Mochida K, Lou YH, Hara A, Yamauchi K (1994) Physical biochemical properties of IgM from a teleost fish. Immunology 83:675-680

Navarro I, Gutierrez J (1995) Fasting and starvation. In: Hochachka PW, Mommsen TP (eds) Metabolic biochemistry. Elsevier, Amsterdam, p 393-434

Olesen NJ, Jørgensen PEV (1986) Quantification of serum immunoglobulin in rainbow trout Salmo gairdneri under various environmental conditions. Dis Aquat Org 1. $183-189$

Partula S, Charlemagne J (1993) Characterization of serum immunoglobulins in a chondrostean fish, Acipenser baeri Dev Comp Immunol 17:515-524

Rombout JHWM, Taverne $N$, van de Kamp M, TaverneThiele AJ (1993) Differences in mucous and serum immunoglobulin of carp (Cyprinus carpio L.). Dev Comp Immunol 17:309-317

Sánchez C, Babin M, Tomillo J, Ubeira FM, Donínguez J (1993) Quantification of low levels of rainbow trout immunoglobulins by enzyme immunoassay using two monoclonal antibodies. Vet Immunol Immunopathol 36:65-74

Takemura A, Takano K (1997) Transfer of maternally-derived immunoglobulin (IgM) to larvae in tilapia, Oreochromis mossambicus. Fish Shellfish Immunol 7:355-363

Wilson MR, Warr GW (1992) Fish immunoglobulins and the genes that encode them. Annu Rev Fish Dis 2:201-221

Yamaguchi N, Teshima C, Kurashige S, Saito T, Mitsuhashi S (1981) Seasonal modulation antibody formation in rainbow trout (Salmo gairdneri). In: Solomon JB (ed) Aspects of developmental and comparative immunology I. Pergamon Press, Oxford, p 483-484

Zapata AG, Varas A, Torroba M (1992) Seasonal variations in the immune system of lower vertebrates. Immunol Today $13: 142-147$

Submitted: February 12, 1998; Accepted: June 22, 1999

Proofs received from author(s): October 12, 1999 